\title{
Performance of Various Cyanide Degrading Bacteria on the Biodegradation of Free Cyanide
}

\author{
L.C. Razanamahandry, C.T. Onwordi, W. Saban, L. Mekuto, E. Malenga, E. Manikandan, E. \\ Fosso-Kankeu, M. Maaza and S.K.O Ntwampe
}

\begin{abstract}
This study reports on the biodegradation of free cyanide (FCN) by cyanide degrading bacteria (CDB) that were isolated from mining wastewater and in thiocyanate containing wastewater. The performance of these isolates was compared to cryopreserved CDBs that were used in precious studies. The performance of the isolates to degrade FCN was studied in batch cultures. It was observed that the CDB from the thiocyanate wastewater showed higher biodegradation rates $\left(2.114 \mathrm{~g} \mathrm{CN}^{-}\right.$ . $\mathrm{L}^{-1} \cdot \mathrm{O}^{\left.-D_{600 \mathrm{~mm}}{ }^{-1} \cdot \mathrm{h}^{-1}\right)}$ compared to the isolates from the mining wastewater. The isolates from the cryopreserved CDBs and from the mining wastewater achieved a biodegradation rate of $1.285 \mathrm{~g}$

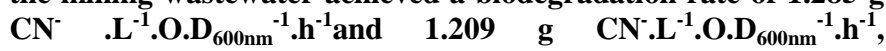
respectively. This study demonstrated that the source of the organisms plays a significant role on FCN biodegradation.
\end{abstract}

Keywords - Cyanide degrading bacteria; Free cyanide; Mining wastewater; Thiocyanate.

L. C. Razanamahandry is with the UNESCO UNISA Africa Chair in Nanoscience's/Nanotechnology Laboratories (U2AC2N), College of Graduate Studies, University of South Africa (UNISA), Muckleneuk Ridge, P.O. Box 392, Pretoria, South Africa and with Nanosciences African network (NANOAFNET), Materials Research Group (MRG), iThemba LABS-National Research Foundation (NRF), 1 Old Faure Road, 7129, P.O. Box 722, Somerset West, Western Cape Province, Cape Town, South Africa.

C.T. Onwordi is with the University of Western Cape, Environmental and Nano Sciences, Department of Chemistry, Faculty of Natural Sciences, , Bellville, Private mail Bag X17, Cape Town, 7535.

W. Saban is with the UNESCO UNISA Africa Chair in Nanoscience's/Nanotechnology Laboratories (U2AC2N), College of Graduate Studies, University of South Africa (UNISA), Muckleneuk Ridge, P O Box 392, Pretoria, South Africa and with Nanosciences African network (NANOAFNET), Materials Research Group (MRG), iThemba LABS-National Research Foundation (NRF), 1 Old Faure Road, 7129, P. O. Box 722, Somerset West, Western Cape Province, Cape Town, South Africa

L. Mekuto is with the University of Johannesburg, Department of Chemical Engineering, Johannesburg, South Africa.

E. Manikandan is with the UNESCO UNISA Africa Chair in Nanoscience's/Nanotechnology Laboratories (U2AC2N), College of Graduate Studies, University of South Africa (UNISA), Muckleneuk Ridge, P O Box 392, Pretoria, South Africa and with Nanosciences African network (NANOAFNET), Materials Research Group (MRG), iThemba LABS-National Research Foundation (NRF), 1 Old Faure Road, 7129, P. O. Box 722, Somerset West, Western Cape Province, Cape Town, South Africa and with Thiruvalluvar University, Department of Physics, TUCAS Campus, Thennangur-604408, Vellore, India

M. Maaza is with the UNESCO UNISA Africa Chair in Nanoscience's/Nanotechnology Laboratories (U2AC2N), College of Graduate Studies, University of South Africa (UNISA), Muckleneuk Ridge, P O Box 392, Pretoria, South Africa and with Nanosciences African network (NANOAFNET), Materials Research Group (MRG), iThemba LABS-National Research Foundation (NRF), 1 Old Faure Road, 7129, P.O. Box 722, Somerset West, Western Cape Province, Cape Town, South Africa
S. K.O. Ntwampe is the founder of Bioresource Engineering Research Group (BioERG), Faculty of Applied Science Department of Biotechnology Cape Peninsula University of Technology, P.O. Box 652, Cape Town 8000, South Africa.

E. Malenga is with the Water Pollution Monitoring and Remediation Initiatives Research Group, School of Chemical and Minerals Engineering, North-West University, Private Bag X1290, Potchefstroom, 2520, South Africa

Elvis Fosso-Kankeu is with the Water Pollution Monitoring and Remediation Initiatives Research Group, School of Chemical and Minerals Engineering, North-West University, Private Bag X1290, Potchefstroom, 2520 , South Africa

\section{INTRODUCTION}

Free cyanide (FCN) is the most toxic form of cyanide compounds [1]. This chemical compound is also the main product that is used in metallurgical processes for precious metal recovery [2].

Effluents containing FCN should be treated before they are realised into the environment to avoid detrimental effects on the environment medium, such as the contamination of fresh water sources and soil pollution [3], which would culminate in deleterious human health outcomes such as: metabolic acidosis, coma, seizures, bradycardia, and lack of response to oxygen treatment [4].

Physical, chemical and biological treatments are the different treatment methods available for FCN [5]. Nevertheless, biological methods are the most applied as the technology is inexpensive and due to the absence of hazards by-products from the process, as seen in most other treatment methods [6]. Microorganisms that are used to degrade FCN, have an ability to break the triple bond between the carbon and nitrogen atoms $(-\mathrm{C} \equiv \mathrm{N})$ in $\mathrm{FCN}$ and use these elements as a carbon or/and nitrogen source for their metabolism [7]. Microorganisms use enzyme to accelerate the bond destruction of FCN [8] with the biodegradation by-products formed, being dependent on the enzyme type that the microorganisms use and the conditions of the bioreactor used, i.e. aerobic or anaerobic conditions [9]. Several pathways are available to biodegrade FCN but the hydrolytic pathway is the most commonly used process [10]. Enzymes for hydrolytic conversion of FCN include nitrogenase, cyanide hydratase, nitrile hydratase, thiocyanate hydrolase, nitrilase, and cyanidase [11] among others. Depending on these enzymes, various by-products from FCN biodegradation could be formed such as: ammonium nitrogen $\left(\mathrm{NH}_{4}{ }^{+} \mathrm{N}\right)$, ammoniac $\left(\mathrm{NH}_{3}\right)$, formate $\left(\mathrm{HCOO}^{-}\right)$, Formamide $\left(\mathrm{HCNOH}_{2}\right)$, Carbonyl sulphide $(\mathrm{COS})$, sulphide $\left(\mathrm{SO}_{3}{ }^{2-}\right)$ and hydrogen sulphide $\left(\mathrm{H}_{2} \mathrm{~S}\right)$ [12]-[16].

However the environmental conditions could affect the 
enzyme activity from the microorganisms known for FCN conversion [17]. These external factors include $\mathrm{pH}$ and temperature, which makes it difficult to choose suitable microorganisms for bioreactors used to biodegrade FCN [18]. However, microorganisms, depending on their species, have an ability to acclimate to new environmental conditions during their latency phase [19]. Huertas et al. [20] have reported a FCN biodegradation latency phase of $20 \mathrm{~h}$ for Pseudomonas pseudoalcaligenes CECT5344 isolated from river water. Generally, most of FCN biodegradation technologies, use different microorganisms sourced the wastewater containing the pollutant of interest, from which a consortia can be engineered. Mekuto et al. [12] have studied FCN biodegradation in FCN contaminated wastewater by using a consortium of different Bacillus sp. and found a similar trend of FCN biodegradation when compared to other studies. Nevertheless, few studies focused on the FCN biodegradation performance by each CDB collected from different sources.

This research was aimed at evaluating the performance of bacteria when their source medium different. This paper also supports a decision on the choice of the suitable source of the CDB for FCN biodegradation for large-scale operations.

\section{MATERIALS AND METHODS}

\section{A. Materials Sources}

Microorganisms $(n=5)$ were tested for their performance to degrade FCN. These microorganisms were collected from different sources.

Three $(\mathrm{n}=3)$ bacterial strains $\left(\mathrm{C}_{1}, \mathrm{C}_{2}\right.$ and $\left.\mathrm{C}_{3}\right)$ conserved at $-80^{\circ} \mathrm{C}$ were obtained from of the BioERG laboratories at the Department of Biotechnology, CPUT, were recultured in Tryptone Soy broth and incubated at $37^{\circ} \mathrm{C}$ for $24 \mathrm{~h}$ before isolation.

Two $(n=2)$ microorganisms, each from mining wastewater $\left(\mathrm{C}_{\mathrm{m}}\right)$ and thiocyanate containing wastewater $\left(\mathrm{C}_{\mathrm{t}}\right)$ were collected from from a mining company in South Africa.

The thiocyanate wastewater was also mixed with wastewater from a previous study in which the effluent was treated [21].

\section{B. CDB Isolation}

Two different media, without nutrients (SN) and with nutrients (AN) were prepared. The $\mathrm{SN}$ medium was enriched using nutrient agar (Merck, South Africa) and $2 \mathrm{~g} \mathrm{CN}^{-} \mathrm{L}^{-1}$ from $\mathrm{KCN}$ (Merck, South Africa). AN medium had the same composition as the $\mathrm{SN}$, with several supplemental nutrient sources and trace metals being added as highlighted in [3]. A volume $(200 \mu \mathrm{L})$ of the mining wastewater and thiocyanate wastewater was spread plated in agar plates constituted by different media, subsequent to incubation at $37^{\circ} \mathrm{C}$ for 7 days to assess microbial growth. The visible colonies on agar plates were grown in Tryptone Soy Broth (TSB) solution at $37{ }^{\circ} \mathrm{C}$ overnight. Microorganisms imaging using a Scanning Electron Microscopy (SEM) was prepared according to [21] but hexamethyldisilazane (HDMS) solution was replaced by silicon tetrachloride solution before SEM visualisation. Microbial samples in TSB solution were centrifuged at $10000 \mathrm{~g}$ for $5 \mathrm{~min}$. and fixation in $2.5 \%$ glutaraldehyde for $24 \mathrm{~h}$ at $4^{\circ} \mathrm{C}$. The glutaraldehyde solution was discarded and the microbial pellets were washed twice by using a phosphate buffer $(\mathrm{pH} 7)$ before dehydration in an ethanol series of $50 \%, 70 \%$ and $100 \%$ during a $12 \mathrm{~h}$ period at $4^{\circ} \mathrm{C}$. Thereafter, silicon tetrachloride solution was used for drying the samples and the final microorganisms pellets were sent for SEM analysis.

\section{FCN Biodegradation Tests}

The observable colonies from the agar plates containing $2 \mathrm{~g}$ $\mathrm{CN}^{-} \mathrm{L}^{-1}$ were streaked and grown in Tryptone Soy broth (Merck, Germany) and thereafter incubated at $37{ }^{\circ} \mathrm{C}$ overnight. The isolates were recultured and tested for their ability to biodegrade free cyanide as KCN (Sigma Aldrich, Germany), in solutions containing 1,2 and $3 \mathrm{~g} \mathrm{CN}^{-} \mathrm{L}^{-1}$ subsequent to use in mining wastewater biodegradation studies. A volume $(1 \mathrm{~mL})$ of the bacterial isolates was added in $99 \mathrm{~mL}$ of the $\mathrm{KCN}$ solution and in $99 \mathrm{~mL}$ of the mining wastewater; an inoculum concentration equivalent to $1 \% \mathrm{v} / \mathrm{v}$. The $\mathrm{pH}$ was set at 8.5 and the temperature was kept at $25^{\circ} \mathrm{C}$, with a constant incubator rotation of $120 \mathrm{rpm}$. $\mathrm{FCN}, \mathrm{NH}_{4}{ }^{+}$concentrations and bacterial growth were quantified every $2 \mathrm{~h}$ over a $24 \mathrm{~h}$ period. Photometric methods were used to measure the $\mathrm{FCN}$ and $\mathrm{NH}_{4}{ }^{+}$concentrations according to the analytical methods reported in Mekuto et al. [22], in which Merck tests kits 09701 and 00683 were used to measure FCN and $\mathrm{NH}_{4}{ }^{+}$concentrations by using Merck Spectroquant Nova 60 instrument, respectively. Bacteria density was quantified at a wavelength of $600 \mathrm{~nm}$ using spectrophotometer (JENWAY 7305 series). At the end of the biodegradation tests, i.e. when the FCN concentration was below the detection limit $(<0.010$ mg $\mathrm{CN}^{-} \mathrm{L}^{-1}$ ), a small volume of the solution was recovered from each test subsequent to drying at $60^{\circ} \mathrm{C}$ for $30 \mathrm{~min}$, samples which were sent for XRD analyses.

\section{CDB Performance Evaluation}

FCN biodegradation performance $\left(\mathrm{P}_{\mathrm{FCN}}\right)$ for each $\mathrm{CDB}$ was calculated according the following equation:

$\mathrm{P}_{\mathrm{FCN}}=\left[\mathrm{FCN}_{\mathrm{i}}\right] \times 1 / \mathrm{BD}_{\mathrm{i}} \times 1 / \mathrm{t}$

Where:

$\left[\mathrm{FCN}_{\mathrm{i}}\right]$ : FCN concentration initial $\left(\mathrm{g}^{\mathrm{L}} \mathrm{L}^{-1}\right)$,

$\mathrm{BD}_{\mathrm{i}}$ : Initially Bacterial Density (O.D.600nm), and

$\mathrm{t}$ : degradation duration $(\mathrm{h})$.

\section{RESULTS AND DISCUSSION}

\section{A. FCN Biodegradation}

FCN biodegradation by various sources of the CDBs have shown a similar trend as presented by the FCN profiles in Figure.1.

Fig.1 (a) shows O.D.600nm of the CDB decreased during the first $4 \mathrm{~h}$ and increased to the optimal value before decreasing again. The initial O.D.600nm of the CDB was respectively 0.055 ; 0.048; 0.050; and 0.035 for $\mathrm{C}_{1}, \mathrm{C}_{2}, \mathrm{C}_{3}, \mathrm{C}_{\mathrm{m}}$ and $\mathrm{C}_{\mathrm{t}}$. After the first 4h, the O.D. $600 \mathrm{~nm}$ values increased from $6 \times 10^{-3}$ to $5 \times 10^{-2} ; 4 \times 10^{-3}$ to $10^{-2} ; 5 \times 10^{-3}$ to $2 \times 10^{-2} ; 5 \times 10^{-3}$ to $10^{-2}$; and $8 \times 10^{-3}$ to $7 \times 10^{-2}$ for $\mathrm{C}_{1}, \mathrm{C}_{2}, \mathrm{C}_{3}, \mathrm{C}_{\mathrm{m}}$ and $\mathrm{C}_{\mathrm{t}}$, respectively. All CDBs tested were able to grow on the medium containing various $\mathrm{FCN}$ concentrations. Nevertheless, from the medium with an FCN 
concentration of $3 \mathrm{~g} \mathrm{CNL}^{-1}$, the $\mathrm{CDB}$ growth was minimal, with the achieved maximum O.D.600nm of 0.007; 0.008; 0.008; 0.01 and 0.014 for $\mathrm{C}_{1}, \mathrm{C}_{2}, \mathrm{C}_{3}, \mathrm{C}_{\mathrm{m}}$ and $\mathrm{C}_{\mathrm{t}}$, being observed respectively. FCN biodegradation rates of $99 \%$ were obtained for all tests after $28 \mathrm{~h}, 37 \mathrm{~h}$ and $72 \mathrm{~h}$ in $1 \mathrm{~g}, 2 \mathrm{~g}$ and $3 \mathrm{~g} \mathrm{CNL}^{-1}$ solutions, respectively.

In addition, $\mathrm{NH}_{4}^{+}$was produced during the $\mathrm{FCN}$ biodegradation tests a by-product. The optimal $\mathrm{NH}_{4}{ }^{+}$ concentration varied in function of the CDB types $\left(0.12 \mathrm{mgL}^{-1}\right.$ for $\mathrm{C}_{1}, 0.08 \mathrm{mgL}^{-1}$ for $\mathrm{C}_{2} ; 0.10 \mathrm{mgL}^{-1}$ for $\mathrm{C}_{3}, 0.05 \mathrm{mgL}^{-1}$ for $\mathrm{C}_{\mathrm{m}}$, and $0.16 \mathrm{mgL}^{-1}$ for $\mathrm{C}_{\mathrm{t}}$ ). The $\mathrm{NH}_{4}^{+}$concentration produced was initially very high than its value at the end of the tests. $\mathrm{NH}_{4}{ }^{+}$was used by the CDB for their growth as highlighted in [23]; as nitrifying $\mathrm{CDB}$ could also convert $\mathrm{NH}_{4}{ }^{+}$to nitrate and nitrite.

Biodegradation of the $\mathrm{FCN}$ leads to $\mathrm{NH}_{4}{ }^{+}$formation as reported by various previous studies on FCN biodegradation [24][25]. The formation of $\mathrm{NH}_{4}^{+}$reveals a $\mathrm{FCN}$ biodegradation by hydrolytic pathway[5].

FCN biodegradation in mining wastewater was achieved in a short period of less than $10 \mathrm{~h}$, i.e. $5 \mathrm{~h}$ for $\mathrm{C}_{\mathrm{t}}(\mathrm{Fig} .1 \mathrm{~b})$ and in $6 \mathrm{~h}$ for $\mathrm{C}_{1}, \mathrm{C}_{2}, \mathrm{C}_{3}$ and $\mathrm{C}_{\mathrm{m}}$. The exponential phase of the bacterial growth was observed after $1 \mathrm{~h}$ of contact time between $\mathrm{CDB}$ and the mining wastewater. Then, $\mathrm{CDB}$ growth declined proportionally with the decreases in the pollutants $\left(\mathrm{NH}_{4}{ }^{+}\right.$and FCN).

The CDB and FCN substrate equilibrium time was 2 and $8 \mathrm{~h}$ for $\mathrm{KCN}$ solution and the mining wastewater, respectively.
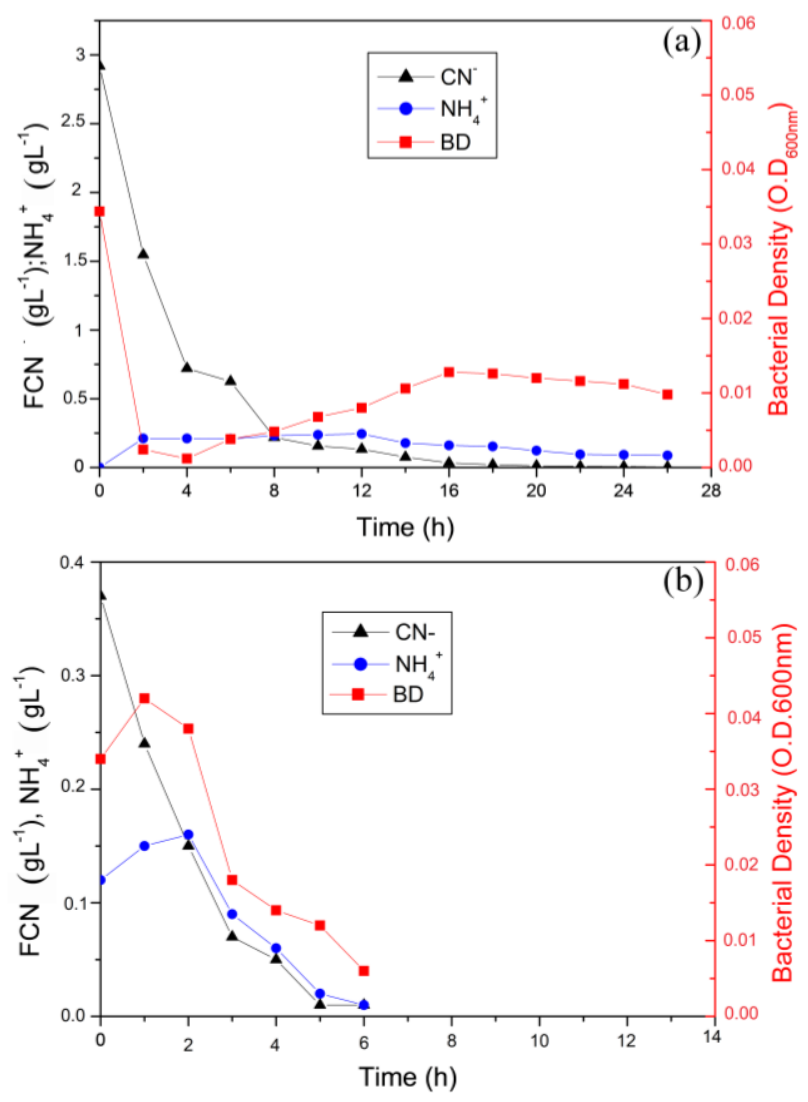

Fig. 1: FCN Biodegradation by $\mathrm{Ct}$ : (a) in $\mathrm{KCN}$ solution synthesised containing $3 \mathrm{~g} \mathrm{CN}^{-} \mathrm{L}^{-1}$ and (b) in Mining wastewater containing $0.37 \mathrm{~g}$ $\mathrm{CN}^{-} \mathrm{L}^{-1}$
Each CDB has its own unique behaviour and performance to degrade FCN. Figure 2 presents the topographic surface of the biomass from different $\mathrm{CDBs}$ used after growing in the medium containing FCN. Two different surfaces were observed for all biomass such as the background surface and the front surface. The background surface formed by the irregular holes represents the biomass support. Same background surface was observed for all biomass. The front surface is specifically for each type of CDB biomass. More gums are observed on the front surface for $\mathrm{C}_{\mathrm{t}}$ biomass followed by $\mathrm{Cm}$ and $\mathrm{C}_{2}$ biomass. $\mathrm{C}_{1}$ and $\mathrm{C}_{3}$ biomass had minimal gums. These gums represents the nutrient and FCN uptake in the biomass [5]. Biofilm biomass embedded in these pollutants could affect the topographic surface of the biomass [5]. Therefore, $\mathrm{C}_{\mathrm{t}}$ embedded highest FCN concentration than $\mathrm{Cm}$ and $\mathrm{C}_{2}$. $\mathrm{C}_{1}$ and $\mathrm{C}_{3}$ have the lowest ability to uptake FCN.
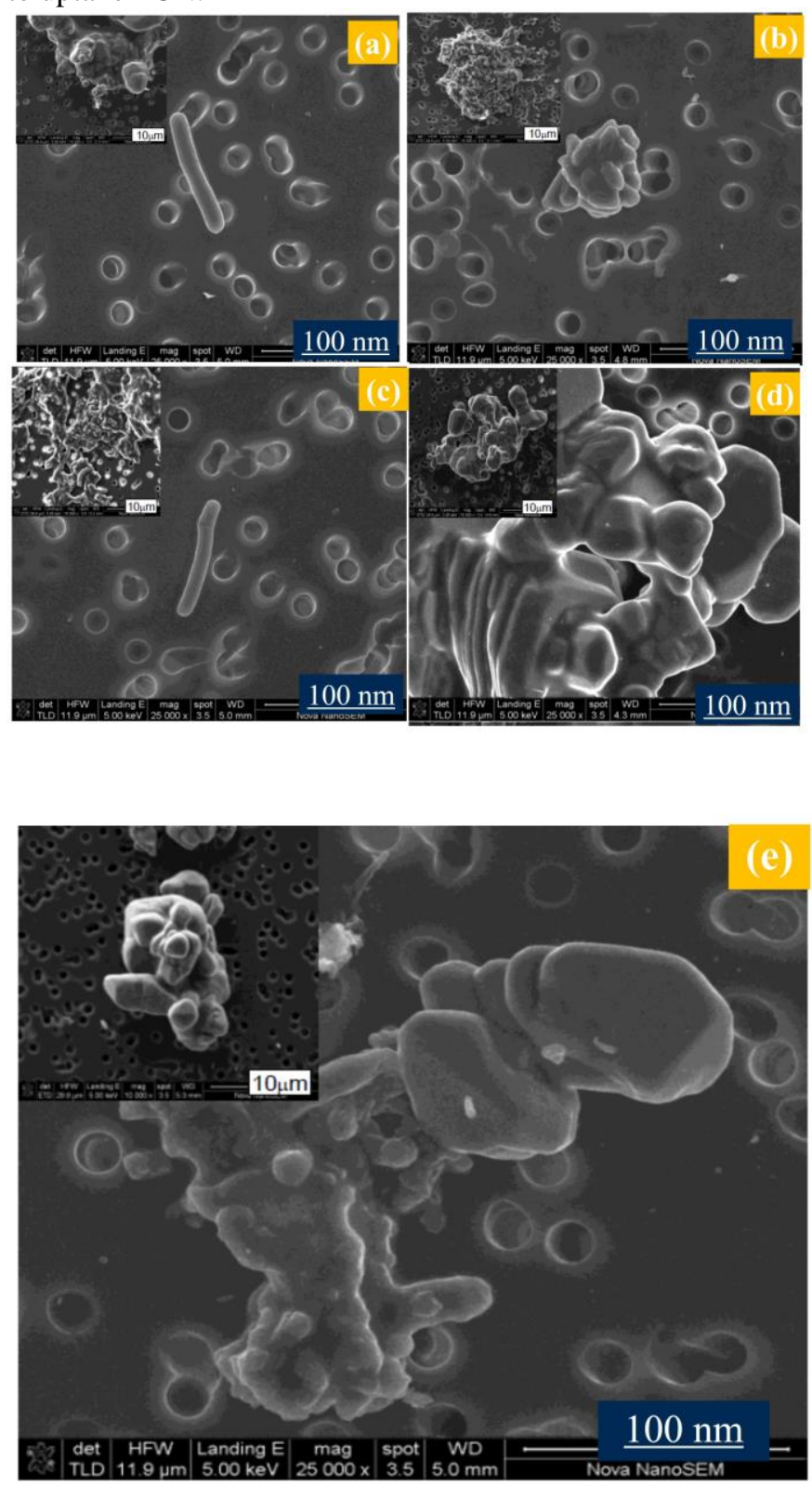

Fig. 2: SEM images: (a) $C_{1}$, (b) $C_{2}$, (c) $C_{3}$, (d) $C_{m}$ and (e) $C_{t}$ 
Besides the by-product i.e. $\mathrm{NH}_{4}{ }^{+}$, some crystallographic materials have been detected in the mixture of FCN and CDB solution, shown as deposits as illustrated in Figure 3.

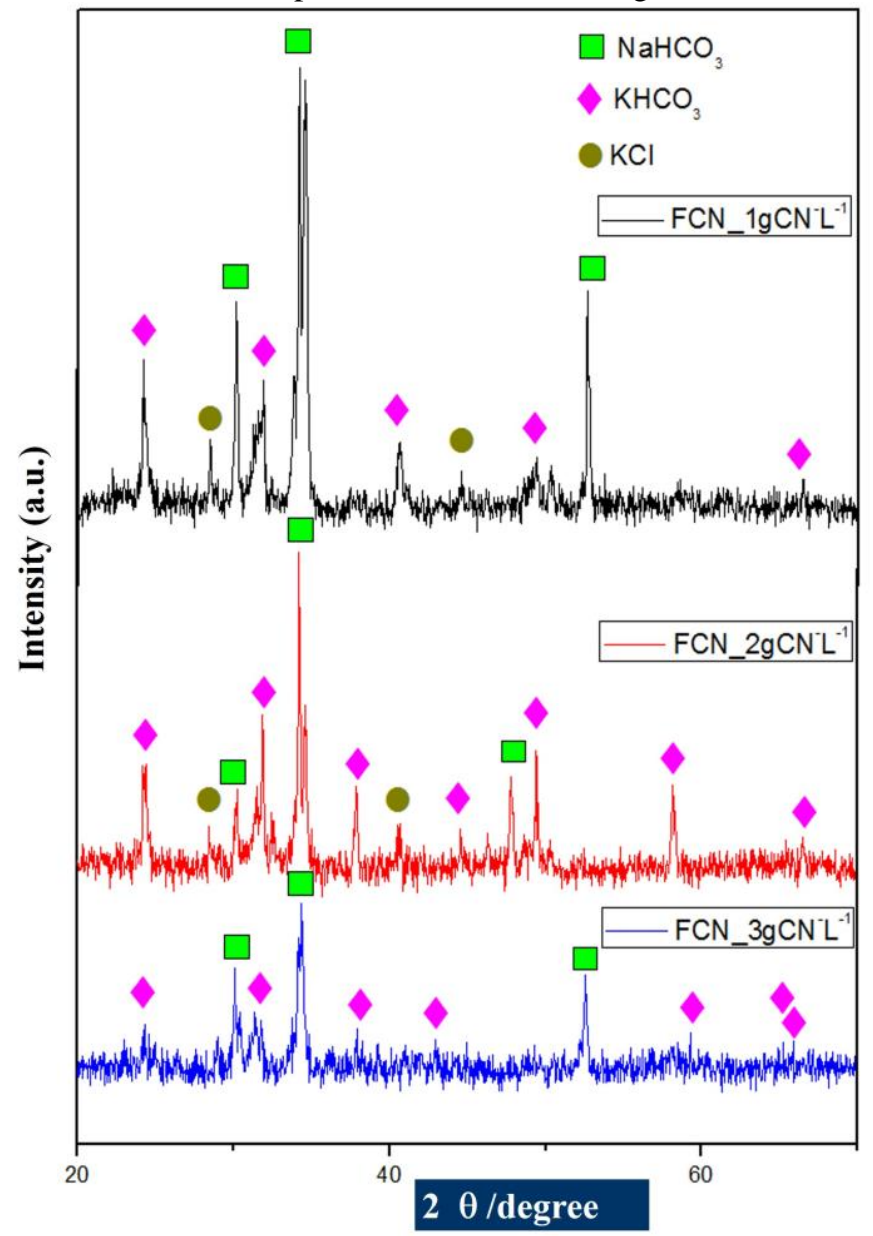

Fig. 3: XRD patterns of FCN solution deposit

Three kind of crystallographic materials Nacholite $\left(\mathrm{NaHCO}_{3}\right)$, Kalicinite $\left(\mathrm{KHCO}_{3}\right)$ and Sylvite $(\mathrm{KCl})$ were produced. The first two products have a monoclinic facial and the third one has a face-centered cubic. The by-product depends on the enzyme used by the CDB to degrade FCN [9].

In addition, Figure 3 shows the absence of the $\mathrm{CN}$ compound as a complex. $\mathrm{CN}$ chemical compounds were determined to have been consumed and/or converted by the CDB since the CDBs can utilise the $\mathrm{CN}$ in their metabolism as reported in [9].

Also, FCN biodegradation by-product peaks are an inverse to the initial FCN concentration being observed in solution; albeit, CDBs had a difficulty in degrading FCN at the highest concentration.

From the XRD profiles, the $\mathrm{KCl}$ disappearance at $\mathrm{FCN}$ concentration of $3 \mathrm{~g} \mathrm{CN}^{-1}$ was evident. This was hypothesised to be a resultant toxicity of the FCN that enabled the non-formation of this by-product at higher concentrations as reported by Kuyucak and Akcil [26].

\section{B. CDB Performance}

CDB performance to degrade FCN is presented in Figure 4. The isolate labelled as $\mathrm{C}_{\mathrm{t}}$ had the highest $\mathrm{P}_{\mathrm{FCN}}$ value (i.e. $1.905 \mathrm{~g}$ $\mathrm{CN}^{-} \cdot \mathrm{L}^{-1} \cdot \mathrm{O}^{-} \mathrm{D}_{600 \mathrm{~m}}{ }^{-1} \cdot \mathrm{h}^{-1}$ for the KCN solution and $2.114 \mathrm{CN}^{-}$ . $\mathrm{L}^{-1}$.O. $\mathrm{D}_{600 \mathrm{~mm}^{-1}} \cdot \mathrm{h}^{-1}$ for the mining wastewater). Isolates $\mathrm{C}_{2}, \mathrm{C}_{3}$ and $\mathrm{C}_{1}$ had similar $\mathrm{P}_{\mathrm{FCN}}$ value of $1.190 \mathrm{~g} \mathrm{CN} \cdot \mathrm{L}^{-1}$.O. $\mathrm{D}_{600 \mathrm{~mm}}{ }^{-1} \cdot \mathrm{h}^{-1}$; $1.176 \mathrm{~g} \mathrm{CN}^{-} \cdot \mathrm{L}^{-1} \cdot \mathrm{O} \cdot \mathrm{D}_{600 \mathrm{~m}}{ }^{-1} \cdot \mathrm{h}^{-1}$ and $1.102 \mathrm{~g} \mathrm{CN}^{-} \cdot \mathrm{L}^{-1} \cdot \mathrm{O} \cdot \mathrm{D}_{600 \mathrm{~nm}^{-1}} \cdot \mathrm{h}^{-1}$ for the KCN solution and $1.285 \mathrm{~g} \mathrm{CN}^{-} \cdot \mathrm{L}^{-1}$.O. $\mathrm{D}_{600 \mathrm{~m}^{-1}} \cdot \mathrm{h}^{-1} ; 1.233 \mathrm{~g}$ $\mathrm{CN}^{-} \cdot \mathrm{L}^{-1} \cdot \mathrm{O} \cdot \mathrm{D}_{600 \mathrm{~m}}{ }^{-1} \cdot \mathrm{h}^{-1}$ and $1.121 \mathrm{~g} \mathrm{CN} \cdot \mathrm{L}^{-1} \cdot \mathrm{O} \cdot \mathrm{D}_{600 \mathrm{~nm}^{-1}} \cdot \mathrm{h}^{-1}$ for the mining wastewater, respectively. Isolate $\mathrm{C}_{\mathrm{m}}$ had the lowest $\mathrm{P}_{\mathrm{FCN}}$ value of $1.06 \mathrm{~g} \mathrm{CN}^{-} \cdot \mathrm{L}^{-1} \cdot \mathrm{O} \cdot \mathrm{D}_{600 \mathrm{~nm}}{ }^{-1} \cdot \mathrm{h}^{-1}$ in the $\mathrm{KCN}$ solution and $1.209 \mathrm{~g} \mathrm{CN}^{-} \cdot \mathrm{L}^{-1}$.O. $\mathrm{D}_{600 \mathrm{~mm}}{ }^{-1} \cdot \mathrm{h}^{-1}$ for the mining wastewater.

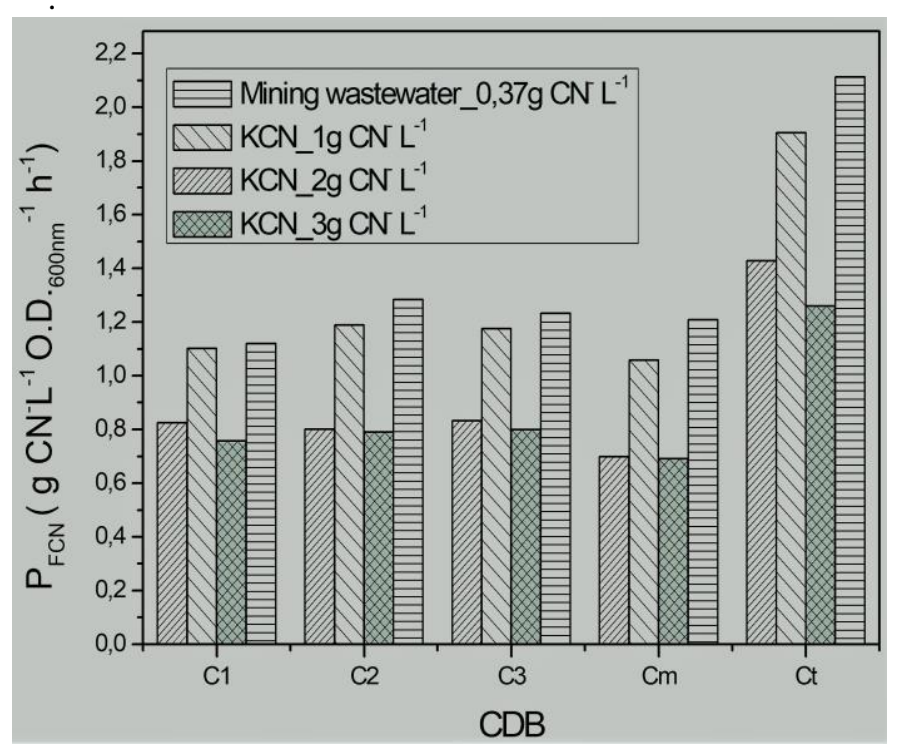

Fig. 4: FCN biodegradation performance $\left(\mathrm{P}_{\mathrm{FCN}}\right)$ by various $\mathrm{CDB}$

These results are similar to biomass SEM images, which revealed the biomass surface of $\mathrm{C}_{t}$, which had a highest $\mathrm{P}_{\mathrm{FCN}}$ value, thus containing the highest gums than $C_{m}$ and $C_{2}$. Biomass surface of $\mathrm{C}_{1}$ and $\mathrm{C}_{3}$, that had the lowest $\mathrm{P}_{\mathrm{FCN}}$ value, contained the lowest gums. Only the biomass $\mathrm{C}_{\mathrm{m}}$, which had very low $\mathrm{P}_{\mathrm{FCN}}$ had shown more gum than $\mathrm{C}_{1}, \mathrm{C}_{2}$ and $\mathrm{C}_{3}$.

$\mathrm{P}_{\mathrm{FCN}}$ for all CDB was very higher for the lowest initially $\mathrm{FCN}$ concentration than the highest initially FCN concentration. FCN concentration of $3 \mathrm{gCN}^{-} \mathrm{L}^{-1}$ was the highest $\mathrm{FCN}$ concentration biodegraded by all CDB types used.

Overall, the initial concentration of FCN could affect its biodegradation [19]

FCN in mining wastewater was easily biodegraded by all CDBs. Mining wastewater liquid medium is rich in trace nutrients such as metals and had an initial FCN concentration that was low $\left(0.37 \mathrm{~g} \mathrm{CN}^{-} \mathrm{L}^{-1}\right)$, thus the ability of the CDBs to effectively remove the pollutant in the wastewater.

\section{CONCLUSION}

CDB from different sources were tested for the biodegradation of free cyanide $(\mathrm{FCN})$. $\mathrm{CDB}$ s that were isolated from the thiocyanate solution $\left(C_{t}\right)$ have shown their potential to degrade the FCN at a higher degradation rate $\left(\mathrm{P}_{\mathrm{FCN}}=2.114 \mathrm{~g}\right.$ $\mathrm{CN}^{-} . \mathrm{L}^{-1} \cdot$ O. $\left.\mathrm{D}_{600 \mathrm{~nm}}{ }^{-1} \cdot \mathrm{h}^{-1}\right)$ as confirmed by the SEM images with a highest gums concentration embedded within the $\mathrm{C}_{\mathrm{t}}$ biomass. Besides $\mathrm{NH}_{4}{ }^{+}$, various crystallographic by-products were also detected after the FCN biodegradation process. Further research will determine the enzymes that the CDBs utilized, in order to explain the reaction mechanism that ensued during FCN biodegradation and evaluate whether they can be recovered for further applications. 


\section{ACKNOWLEDGMENTS}

The authors would like to acknowledge the National Research Foundation (NRF)-TWAS, the UNESCO-UNISA Africa Chair in Nanosciences/Nanotechnology Laboratories, College of Graduate Studies, University of South Africa (UNISA), Muckleneuk Ridge, Pretoria, South Africa, and Bioresource Engineering Research Group (BioERG) for the support received for this research under Unique Grant No 110793.

\section{REFERENCES}

[1] C. Candeias, P. Ávila, P. Coelho, and J. P. Teixeira, Mining Activities: Health Impacts, 2nd ed. Elsevier Inc., 2018.

[2] L. Mekuto, S. K. O. Ntwampe, and J. B. N. Mudumbi, "Microbial communities associated with the co-metabolism of free cyanide and thiocyanate under alkaline conditions," 3 Biotech, vol. 8, no. 93, pp. https://doi.org/10.1007/s13205-018-1124-3, 2018

[3] L. C. Razanamahandry, H. A. Andrianisa, H. Karoui, K. M. Kouakou, and H. Yacouba, "Biodegradation of free cyanide by bacterial species isolated from cyanide-contaminated artisanal gold mining catchment area in Burkina Faso," Chemosphere, vol. 157, pp. 71-78, 2016. https://doi.org/10.1016/j.chemosphere.2016.05.020

[4] V. M. Luque-Almagro, C. Moreno-Vivián, and M. D. Roldán, "Biodegradation of cyanide wastes from mining and jewellery industries," Curr. Opin. Biotechnol., vol. 38, pp. 9-13, 2016.3 https://doi.org/10.1016/j.copbio.2015.12.004

[5] E. A. Akinpelu, A. T. Adetunji, S. K. O. Ntwampe, F. Nchu, and L. Mekuto, "Performance of Fusarium oxysporum EKT01 / 02 isolate in cyanide biodegradation system," vol. 23, no. 2, pp. 223-227, 2018.

[6] R.Kumar, S. Saha, S. Dhaka, M. B. Kurade, C. U. Kang, S. H. Baek \& B.-H. Jeon., "Remediation of cyanide-contaminated environments through microbes and plants : a review of current knowledge and future perspectives," Geosystem Eng., vol. 9328, no. April, pp. 1-13, 2017. https://doi.org/10.1080/12269328.2016.1218303

[7] S. Mirizadeh, S. Yaghmaei, and Z. Ghobadi Nejad, "Biodegradation of cyanide by a new isolated strain under alkaline conditions and optimization by response surface methodology (RSM).," J. Environ. Heal. Sci. Eng., vol. 12, no. 1, p. 85, 2014. https://doi.org/10.1186/2052-336X-12-85

[8] V. M. Luque-Almagro, R. Blasco, M. Martínez-Luque, C. Moreno-Vivián, F. Castillo, and M. D. Roldán, "Bacterial cyanide degradation is under review: Pseudomonas pseudoalcaligenes CECT5344, a case of an alkaliphilic cyanotroph.," Biochem. Soc. Trans., vol. 39, no. 1, pp. 269-74, Jan. 2011 https://doi.org/10.1042/BST0390269

[9] L. C. Razanamahandry, H. Karoui, H. A. Andrianisa, and H. Yacouba, "Bioremediation of soil and water polluted by cyanide: A review," African J. Environ. Sci. Technol., vol. 11, no. 6, pp. 272-291, 2017. https://doi.org/10.5897/AJEST2016.2264

[10] P. Gupta, T. R. Sreekrishnan, and Z. A. Shaikh, "Application of hybrid anaerobic reactor: Treatment of increasing cyanide containing effluents and microbial composition identification," J. Environ. Manage., vol. 226, no. August, pp. 448-456, 2018 https://doi.org/10.1016/j.jenvman.2018.08.023

[11] N. Gupta, C. Balomajumder, and V. K. Agarwal, "Enzymatic mechanism and biochemistry for cyanide degradation: a review.," J. Hazard. Mater., vol. 176, no. 1-3, pp. 1-13, Apr. 2010. https://doi.org/10.1016/j.jhazmat.2009.11.038

[12] L. Mekuto, V. A. Jackson, and S. K. O. Ntwampe, "Biodegradation of Free Cyanide Using Bacillus Sp . Consortium Dominated by Bacillus Safensis , Lichenformis and Tequilensis Strains : A Bioprocess Supported Solely with Whey," Bioremediation Biodegrad., no. 18, pp. 1-7, 2013.

[13] H. G. Shete and B. P. Kapdnis, "Production and Characterization of Cyanide Hydratase from Micromonospora braunna Abstract :," Univers. J. Environ. Res. Technol., vol. 2, no. 6, pp. 609-615, 2012.

[14] A. U. Chaudhari and K. M. Kodam, "Biodegradation of thiocyanate using co-culture of Klebsiella pneumoniae and Ralstonia sp.," Appl. Microbiol. Biotechnol., vol. 85, no. 4, pp. 1167-74, Jan. 2010. https://doi.org/10.1007/s00253-009-2299-7
[15] X.M. Xu; Q. Zhu; M.C. Deng; L. Feng; J. Peng; J.P. Yuan and J.H.Wang, "An effective method for the detoxification of cyanide-rich wastewater by Bacillus sp. CN-22.," Appl. Microbiol. Biotechnol., vol. 98, no. 8, pp. 3801-7, Apr. 2014. https://doi.org/10.1007/s00253-013-5433-5

[16] B. A. Q. Santos, S. K. O. Ntwampe, J. H. Doughari, and G. Muchatibaya, "com Application of Citrus sinensis Solid Waste as a Pseudo- Catalyst for Free Cyanide Conversion under Alkaline Conditions," BioResources, vol. 8, no. 3, pp. 3461-3467, 2013. https://doi.org/10.15376/biores.8.3.3461-3467

[17] L. Wang, J. M. Watermeyer, A. E. Mulelu, B. T. Sewell, and M. J. Benedik, "Engineering $\mathrm{pH}$-tolerant mutants of a cyanide dihydratase.," Appl. Microbiol. Biotechnol., vol. 94, no. 1, pp. 131-40, Apr. 2012. https://doi.org/10.1007/s00253-011-3620-9

[18] V. Kumar, V. Kumar, and T. C. Bhalla, "In vitro cyanide degradation by Serretia marcescens RL2b," Int. J. Environ. Sci., vol. 3, no. 6, pp. 1969-1979, 2013.

[19] A.-R. Bouari, S. A. Begum, and N. O. Egiebor, "Bioremediation of Complex Cyanide Contaminated Wastewater using Pseudomonas Fluorescens Pf-5," Int. J. Eng. Res. Technol., vol. 2, no. 9, pp. 1485-1493, 2013.

[20] M. J. Huertas, L. P. Saez, M. Rolda, V. M. Luque-Almagro, and M. et al. Martinez-Luque, "A Alkaline cyanide degradation by Pseudomonas pseudoalcaligenes CECT5344 in a batch reactor.Influence of $\mathrm{pH} .$, , $J$. Hazard. Mater., vol. 179, pp. 72-78, 2010.

https://doi.org/10.1016/j.jhazmat.2010.02.059

[21] L. Mekuto; S. K.O. Ntwampe; C. E. Utomi; M. Mobo; J.B. Mudumbi; M. M. Ngongang and E. A. Akinpelu, "Performance of a continuously stirred tank bioreactor system connected in series for the biodegradation of thiocyanate and free cyanide," J. Environ. Chem. Eng., vol. 5, no. 2, pp. 1936-1945, 2017 https://doi.org/10.1016/j.jece.2017.03.038

[22] L. Mekuto, S. K. O. Ntwampe, M. Kena, M. T. Golela, and O. S. Amodu, "Free cyanide and thiocyanate biodegradation by Pseudomonas aeruginosa STK 03 capable of heterotrophic nitrification under alkaline conditions," 3 Biotech, vol. 6, no. 1, pp. 1-7, 2016.

[23] A. Dzombak and M. Rajat, S., Wong Chong, "Cyanide in water and soil." p. 638, 2015.

[24] L. Mekuto, L. C. Razanamahandry, S. K. O. Ntwampe, J. B. N. Mudumbi, and G. Muchatibaya, "Process performance determination data in thiocyanate biodegradation systems: Use of sulphate production," Data Br., vol. 17, pp. 275-278, 2018. https://doi.org/10.1016/j.dib.2018.01.017

[25] E. A. Akinpelu, O. S. Amodu, N. Mpongwana, S. K. O. Ntwampe, and T. V Ojumu, "Utilization of Beta vulgaris Agrowaste in Biodegradation of Cyanide Contaminated Wastewater," Biotechnology, pp. 59 - 75, 2015.

[26] N. Kuyucak and A. Akcil, "Cyanide and removal options from effluents in gold mining and metallurgical processes," Miner. Eng., vol. 50-51, pp. 13-29, Sep. 2013. https://doi.org/10.1016/j.mineng.2013.05.027

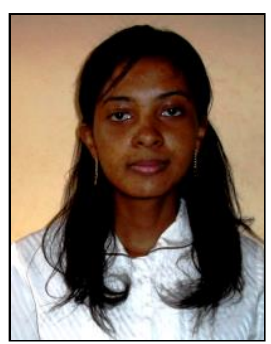

C.L. Razanamahandry was born in Betroka Madagascar in 1989. She is holder of both a Master of Agronomy, Water and Forest option from Superior School of Agronomic Science (ESSA) in 2013, Antananarivo, Madagascar and a Master of Hydraulics from Superior Polytechnic School of Antananarivo (ESPA) and the International Institute for Water and Environmental Engineering under a mobility program in 2014. She has done her $\mathrm{PhD}$ on Cyanide Environmental pollution generated by the artisanal gold mining activities and its bioremediation at the International Institute for Water and Environmental Engineering, Ouagadougou, Burkina Faso, receiving her $\mathrm{PhD}$ degree in Water and Environmental Science in 2017.

Currently, she is doing her full Post-Doctoral fellowship on the application of green nanoparticles on the mining waste water treatment, at iThemba-LABS, Cape Town, South Africa and have got a contract as an international Consultant on Environmental and Engineering field agent and she is currently an associate member of Bioresource Engineering Research Group (BioERG) at the Faculty of Applied Science Department of Biotehnology Cape Peninsula University of Technology, Cape Town, South Africa 
Dr. Razanamahandry is a fellow of Union European under PIMASO program, a fellow of Swiss Cooperation for Development, a fellow of National Research Foundation and TWAS. She has participated numerous oral presentations around the world (Burkina Faso, Tunisia, Senegal, Switzerland, Mexico, and Australia) and published four papers in various Elsevier Ltd. journals such as Chemosphere (2016), Catena (2018) and Data in Brief (2018) and in regional Academic journal such as the African Journal of Environmental Science and Technology (2017).

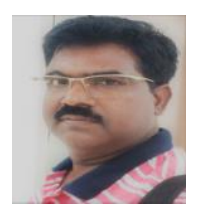

Prof. Dr. E. Manikandan currently working as a Professor and head of the department of Physics at Thiruvalluvar University, Vellore. He's received the Ph.D. degree from the Indira Gandhi Centre for Atomic Research (IGCAR), Kalpakkam jointly Annamalai University, India, and the M.Sc. and M.Phil. Degrees from Bharathidasan and Pondicherry Central University. During his Ph.D. work, he was a key component in developing atomic-nuclear-based accelerator spectroscopy ion beam lines of PIXE/PIGE and high-resolution RBS. He is currently concentrated on modern materials, like nano-metal-oxides/sulphide thin-films and carbon ancestor's materials jointly with Europe, USA, and South African-CSIR Foremost Laboratory. His multipolar scientific /analytical /technical expertise has been of a great, if not a cornerstone assistance to the South African National Nanocentre-Council for Scientific and Industrial Research, where he spent his post-doctoral period followed by a senior research scientist position at the same Centre in Pretoria. He honoured by UNESCO-UNISA Africa, as a Senior Fellow of the Chair in Nanosciences and Nanotechnology and the NANOsciences-African NETwork: NANOAFNET both are UN recognized platforms with full and sustainable resources. He is guiding six PG, 4-Ph.D., and two PDF students. He has authored > 100+ international journals, including nature research highlights for the singular nanostructured thin-films for solar-energy harnessing applications and his present $\boldsymbol{h}$ index 30 (Scopus); google scholar: $\sim 35$ with closely 3000 citations. 